\title{
Gyermekjólét és gyermekvédelem a Covid-19 idején
}

Mi történt a járványügyi helyzetben a gyermekjóléti és gyermekvédelmi területen, hogyan értelmezhetők a gyermeki jogok, mit tanultunk a helyzetből, mi tartható meg a gyermekjólét és gyermekvédelem praxisában? Erröl beszélgettünk 2020. 06. 18-án az ELTE Szociális Munka Tanszék szervezésében megvalósított Tanszéki csütörtök c. rendezvényen.

A panelbeszélgetés résztvevői a kar jelenlegi és volt hallgatói voltak, akik gyakorlati tapasztalataikat és kutatási eredményeiket osztották meg az érdeklődőkkel egy-egy szakmai területet képviselve:

- Zséli Tímea - családsegítés, gyermekjólét (ELTE ÁJK)

- Tanító Zsófia - iskolai szociális munka (ELTE TáTK doktorandusz)

- Bán Dóra - családok átmeneti otthona (ELTE TáTK)

- Joó Beatris - gyermekotthoni ellátás (Gyermekhíd Alapítvány, ELTE TáTK alumna)

- Jonkl Marianna - nevelőszülőség (ELTE TáTK)

- Molnár Zsuzsanna - közösségi támogatások (Kontúr Közhasznú Egyesület, ELTE TáTK alumna)

- Boros Ilona - gyermeki jogok (TASZ, ELTE TáTK alumna)

A beszélgetést moderátora: Rácz Andrea, szociológus, a Szociális Munka Tanszék oktatója.

Rácz Andrea: A mai beszélgetésen két témát járunk körbe: 1) Mi történt a gyermekjóléti és gyermekvédelmi területen a járványügyi helyzetben? és 2) Mit tanulhatunk mind ebböl, mit építhetünk be a praxisba?

\section{Mi történt a gyermekjóléti és gyermekvédelmi területen a járványügyi helyzetben?}

Zséli Tímea: A járvány megfékezésére hozott intézkedések annak érdekében, hogy a személyes kontaktot korlátozzák, négy úton fejtette ki a hatását véleményem szerint a családsegító és gyermekjóléti szolgálatok szintjén. Fontos változás, hogy az iskolák átálltak a digitális oktatásra, így segítséget kellett nyújtani a szülőknek, gyermekeknek, sok esetben az eszközök sem álltak rendelkezésre. A másik fontos probléma a gyámhivatalok müködéséhez kapcsolódik, a hatósági eljárás keretében tárgyalás nélkül, papírokból döntöttek egy gyermek veszélyeztetettségének fennállásáról. Ugyan nyilatkoztatták írásban a szülőket, de korábban előfordult, hogy egy gyermek a szülő jelenléte nélkül szeretett volna valamit mondani a gyámhivatalnak, erre most nem volt lehetöség. Harmadikként megemlíthető, hogy a családsegítő és esetmenedzseri munkakörben dolgozókra is nagy nyomás nehezedett, nagyrészt csak azokkal a családokkal tudtunk találkozni, akik krízishelyzetben voltak. A régi ügyfelekkel telefonon valósult meg a kapcsolattartás, amely ugyancsak aggályokat vet fel, mivel kikerültek a látótérből. A jelzőrendszer gyakorlatilag vakká vált. A családokra nagy nyomás nehezedett ebben az időszakban, mélyült a szegénység. Sokan elvesztették a munkájukat és így a mi munkánk, feladatkörünk bővült azzal, hogy adományokat kutassunk fel és osszunk. Ez is megmutatta, hogy a rendszer nem volt felkészülve egy hasonló helyzetre, mivel alig voltak 
támogatásaink, most több civil szervezettel kerültünk kapcsolatba és azt látjuk, hogy ez sem elegendő, mert nem tudunk mindenkinek adni, akinek szüksége lenne rá. Az oktatás terén is megmutatkozott a szülökre nehezedő nyomás, mert nagy eltérések vannak az iskolák között. Voltak, akik becsülettel megszervezték az online oktatást és leadták a tananyagot, viszont olyan iskolára is volt precedens, akik feladták a leckét, gyakorlatilag készüljenek fel a gyerekek otthon. Nem mindegyik szülö tudja segíteni a gyermeket az iskolai felkészülésben, így megint bővült a feladatkörünk, korrepetálást kellett ellátnunk, amire a kompetenciánk nem terjedt ki. És végül negyedikként kiemelném, hogy megjelentek a kapcsolattartási problémák új szintjei, hogy a szülők felhasználták a COVID-ot arra, hogy megtagadják a kapcsolattartást az elvált szülőpártól.

Tanító Zsófia: A Pinokkió Gimnázium, Szakgimnáziumban úgynevezett osztálysegítőként dolgozom, ami az iskolai szociális munkának egy elég speciális válfaja. Hozzám egy 10.-es osztály tartozik, egy osztálynyi diákért vagyok felelős, úgyhogy a diákoknak csak egy elég szük, bár szociokulturális szempontból nagyon vegyes keresztmetszetéről tudok most beszélni. Szerencsém volt, mert megvolt a gyerekekkel a kapcsolatom korábbról. Elég jó és bizalmi kapcsolatban vagyok velük, így erre a kapcsolatra lehetett építeni és szerencsére meg tudott maradni a karantén alatt, nem csak a diákokkal, hanem a szüleikkel, gondviselöikkel is. Azért is szerencsém volt, mert a járvány időszaka előtt is a mindennapjaim, a munkám része volt a diákokkal és szüleikkel való kapcsolattartás az online térben, az online és az offline tér közötti váltás tehát nem okozott ebből a szempontból akkora nehézséget. Azt, hogy miben kellett segíteni a diákokat, illetve a családjaikat, azt tematizálta a járvány. Foglalkoznunk kellett az eszközellátással, sokszor a saját személyes hálózatunkon keresztül szereztünk telefont, laptopot, tabletet. A karantén időszak elején nagyon sokat kellett foglalkoznunk a bezártság érzésével, amit nyilván kamaszként kifejezetten nehéz lehetett megélni, illetve a napirend kialakításában is igyekeztünk segíteni őket. Azzal is kellett foglalkoznunk, hogy a járvánnyal kapcsolatban milyen információkhoz jutnak a diákok, hogy honnan tájékozódnak, hogy mi az, amit releváns információnak tekinthetnek. A kapcsolat folyamatos, intenzív fenntartása napi szinten állított kihívás elé minket.

Bán Dóra: A családok átmeneti otthonában éltem át a járvány időszakát. A kijárási tilalmat nehezen élték meg a családjaink, a kollégák részéről azonnali döntést követelt meg ez a helyzet, 24 órás müszakra álltunk át. Szinte 2 naponta érkeztek a minisztériumi utasítások, amikkel nagyon sok probléma volt, mert ellentmondásokat tartalmaztak és életidegenek voltak. A pénzfelvételtől kezdve a gyógyszerkiváltásig, bevásárláson át mindent nekünk kellett megcsinálni. A napi 24 órás müszakkal megszünt az a szociális munka és családgondozás, amit a hétköznapi munkavégzésben biztosítottunk. Egymást segítettük mindenféle kommunikációs eszközön. Az étkeztetés volt, amit rögtön meg tudtunk oldani. A digitális oktatást viszont nehéz volt megszervezni, mert a szülőknek nagy terhet jelentett, így alapvetően a kollégák tanultak a gyerekekkel. Nagyon jók voltak a visszajelzések, az iskolai szociális munkásaink nagyon sokat segítettek a pedagógusokkal, általában az iskolákkal való kapcsolatfelvételben. A digitális oktatásban többféle online felületet használtunk, ez is problémát jelentett a napi életszervezés szintjén.

Joó Beatris: A Gyermekhíd Alapítványt Vásári Tamás zongoramüvész, karmester alapította. Amire mi a hangsúlyt fektetjük, az a gyerekek érzelmi fejlesztése, érzelmi támogatása. Amit látunk, hogy ha a gyerekek bekerülnek a gyermekotthonba, már egy korai kötődési traumával rendelkeznek és olyan további szenvedéseket élnek át a kiemelési procedúra során, illetve a gyermekotthonba és az új iskolai közegbe való beilleszkedés során, hogy szinte minden haragjukat, minden fájdalmukat a gyermekotthon nevelöire, gyermekfelügyelöire, jelenlévő szakemberekre vetítik ki. A gyermekotthonokban nagyon sok nevelő cserélődik, ezért nincsen egyetlen stabil személy az ő életükben, akire számíthatnak. Amikor mi elindítottuk a 
foglalkozásainkat, akkor első körben fejlesztő játékos foglakozásokat vittünk több gyermekotthonba, és akkor rájöttünk, hogy pont ez az, amit nem kellene csinálnunk, hanem meg kellene maradnunk stabilan egy helyen, és utána ezt a stabilitást biztosítani több intézmény számára. Így vagyunk jelen négy gyermekotthonban, és minden foglalkozásunk alapja, hogy az önkéntes és a gyermek között létrejövő bizalmi kapcsolattal dolgozunk és így fejlesztjük a gyerekeket. Van egyéni fejlesztöprogramunk, ez az ún. mentor programunk, van közösségfejlesztő programunk, amikor minden önkéntes és minden gyerek együtt van, pszichológusokkal segítjük még a gyerekeket. Szupervíziót biztosítunk a nevelőknek és egy saját önkéntes rendszert dolgoztunk ki, annak érdekében, hogy az önkénteseinknek megfelelő szakmai háttértudást tudjunk biztosítani, illetve megfelelő mentálhigiénés támogatást. A személyes kapcsolaton van a hangsúly és az utóbbi hónapokban pont ez akadozott, majdnem megszakadt, hiszen a járvány alatt a látogatási tilalom miatt az önkénteseink nem mehettek be a gyerekotthonokba és a gyerekotthonokból sem jöhettek ki a gyerekek. A szupervíziót sem tudtuk biztosítani, hiszen nem volt lehetőség a személyes találkozásra, ekkor merült fel, hogy helyezzük át ezt az egész támogatási rendszert az online térbe, de kiderült, hogy több gyermekotthon nem rendelkezik megfelelő digitális eszközzel. Rögtön belekezdtünk egy eszközgyüjtésbe és az UNIQA Biztosítóval együtt elindítottunk egy nagyszabású kampányt, ahol tableteket és pénzt gyüjtöttünk, amit később szétosztottunk az intézményekben élő gyermekeknek. Az önkéntesek segítettek a digitális oktatás nehézségeit áthidalni. Sok gyerek felhasználta a nevelők és az önkéntesek ellen, hogy ebben az időszakban nem érte őket külső inger és feszegették a határaikat. Azt tapasztaltuk, hogy a lakásotthonokban sokkal kiegyensúlyozottabbak a gyerekek a kisebb létszám miatt.

Jonkl Marianna: Az országos gyermekvédelmi módszertani hálózatnak a munkájáról tudok beszélni: a hálózaton belül müködik a nevelöszülöi módszertani hálózat is, ez csaknem lefedi az ország egészét, van még emellett egy gyermekotthoni és egy szakszolgáltatások területén müködő hálózat is. A járványhelyzet miatt gyakrabban találkoztunk online formában. Próbáltuk a minisztériumi útmutatókat követni, de azok nem tértek ki minden problémára, így ezeket gondoltuk át és dolgoztunk ki anyagokat a szakembereknek. Kérdés volt, hogy személyes jelenléttel mennyire lehet támogatást nyújtani a krízishelyzetben. A gyakorlat kialakította a válaszokat, a nevelőszülők nagy része kertes házban lakik, ezért meg lehetett valósítani a személyes találkozót a járványügyi előírások betartásával a szabad levegőn, mind a tanácsadók, mind a pszichológusok részéről. A nevelöszülőknél az oktatás segítése volt egy kardinális probléma, ami nagyon megterhelte őket. És aki maga is nagyon félt az életkora, egészségügyi állapota vagy a családja miatt a vírustól, annak nehezebb volt a bezártságot megélni, mentálisan elfáradtak a családok is. Elmondható még a Gyerekvédő hívószámról, hogy a kapcsolattartások miatt sok információkérés érkezett.

Molnár Zsuzsanna: A Kontúr Egyesület önkéntese vagyok, mi a Hős utcában vagyunk jelen nyolcan. A felnőtteknek föleg a lakhatási problémákkal kapcsolatban segítünk, illetve az ott élő gyerekeknek szervezünk programokat. Arra készültünk, hogy három kiemelt feladatuk lesz: 1) segíteni informálódni az ott élő embereknek, 2) segélycsomagokat szervezni és 3 a gyerekeknek segíteni, hogy kapcsolatot tudjanak tartani az iskolával. Volt egy olyan félelem, hogy mi lesz, ha betör a járvány erre a mindentől elzárt, sürün lakott telepre, akkor nyilvánvalóan gyorsan fog terjedni. Azt gondoltuk, hogy az lesz a működésünk módja, hogy az állami szociális és gyermekvédelmi intézményi rendszerben segítünk irányítani az itt élőket a felmerülő problémák rendezésére. Illetve a nagyobb karitatív szervezetek akcióival összekötni őket, de elég hamar kiderült, hogy ezek a dolgok nem nagyon léteznek. A digitális oktatás sok helyen elbukott. Rendkívül alacsony színvonalú a közoktatási rendszer és ebben a helyzetben ez kicsúcsosodott. A szociális és gyermekvédelmi rendszer nem ért el a kerületnek erre a 
legszegényebb részére. Voltak segélycsomagok ebben a kerületben, de ide egy sem jutott el belölük, szerintem ez egy nagyon komoly diszfunkcióra világít rá. Az itt élő emberek teljesen kétségbe voltak esve, hívogattak minket, hogy segítsünk, mert éhen fognak halni, ami inkább a jövőtől való rettegést, mint a konkrét éhezést fejezte ki. Mi a többi civil szervezet segítségével próbáltunk nekik segíteni. Nagyon pozitív tapasztalat volt a civil szervezetek együttmüködése. Pár hét után minden nap volt meleg étel osztás, Szabó Győző, Molnár Áron segített és sajtót is vonzott magával, ami sok dilemmát felvet, hogyan jó és szabad segíteni kirekesztett helyzetben élő embereknek a személyiségi jogaikat figyelembe véve és tiszteletben tartva.

Boros Ilona: Én a Társaság a Szabadságjogokért civil szervezetnél dolgozom jogászként, így mi nem a gyermekvédelmi rendszer valamelyik szegmensében dolgozunk. A mi feladatunk az volt a járvány alatt, hogy az összevissza érkező információ-tengerben megpróbáljuk tájékoztatni az embereket, mi történik valójában. Nagyon nagy horderejü jogszabály változtatásokat jelentett be a kormányzat, sokszor közösségi oldalakon, majd a jogszabályban egészen más tartalom volt, ez jogi értelemben teljesen abszurd, megengedhetetlen. Nagyon sok jogsegély-megkeresés érkezett hozzánk, annyi az elmúlt három hónap alatt, mint máskor egy év alatt. Ezért a honlapra kisokosokat készítettünk, amivel tájékoztatni próbáltuk az embereket. Ezen túl petíciókat írtunk, például a szociális ellátórendszerben dolgozók fizetésének emeléséért, illetve a szociális ellátások finanszírozásáért. Kezdeményeztünk vagy részt vettünk egyéb olyan szakmai érdekérvényesítésben, amely a járványban legjobban érintettek, pl. a hátrányos helyzetü gyermekek szegregációja ellenében indult. A gyermekvédelmi szakellátásból is nagyon sok segélykiáltás érkezett felénk, amelyekre nehéz volt válaszolni, segíteni, hiszen kritikus a szakellátás állapota.

Rácz Andrea: Nagyon sok negatívumra irányítottátok rá a figyelmet. A gyermekjólét és gyermekvédelem minden szintjén elmondható, hogy a szülökre a korábban már jól ismert nyomás még erősebben nehezedett rá, és teljesen más típusú problémákkal is szembe kellett nézniük, a saját élethelyzetük változása kapcsán is, mint az otthoni munkavégzés, digitális oktatás segítése, gondozási terhek megnövekedése. A szakmai kompetencia határok sok esetben összemosódtak. Nyilván csak bizalmi kapcsolatban lehet bármilyen együttmüködést építeni, az alap-, illetve szakellátásban is többeteknek az volt a tapasztalata, hogy ez sokszor hiányzott. Az online forma is csak ott müködött jól, ahol korábban is volt ennek hagyománya. Beszéltetek a szakellátásban a traumatizált gyermekkorról, a kielégítetlen ellátási szükségletekröl, a hiányzó szakemberekről, a pedagógiai eszközök hiányosságairól, amelyek még inkább láthatóvá váltak. Érdekes, hogy megjelent egy erőteljes civil összefogás, de folyamatosan az önkormányzati és állami struktúra hiányosságait a társadalompolitika összes szintjén tudtuk tapintani. Kifeszülnek az emberi jogok, a gyermekjogok, a régi problémák mellett számos új is keletkezett, mint ahogy a jogsegélyek száma is drasztikusan megnőtt. Mi az, ami megtartható nektek, mint szakmai gyakorlat vagy jó gyakorlat, innovatív megoldás és beépíthető a munkátokba és mi az, ami a hiányok, problémák kapcsán egy másfajta beavatkozást vagy szemléletváltást sürget a teljes gyermekvédelemben?

\section{Mit tanulhatunk mind ebből, mit építhetünk be a praxisba?}

Zséli Tímea: Túl sok jó nem történt, viszont sokkal több szervezettel kerültünk kapcsolatba, ezt érdemes lenne megtartanunk a későbbiekben is. Pozitívumként emelném ki, hogy az iskolákkal amúgy is jó volt a kapcsolatunk, és ez erősödött. Néhány gyermek kikerült a 
látókörükből, nem jelentkeztek be az online oktatásra, nem küldték vissza a feladataikat, ezáltal szorosabbá vált a kapcsolatunk az iskolákkal. Az iskolák kialakították, hogy melyek azok az online platformok, amiken dolgoznak, így, ha lesz egy második hullám, akkor ezeket a felületeket már könnyebb lesz kezelni.

Tanító Zsófia: Öt pozitívum volt véleményem szerint: 1) A lemorzsolódást úgy próbáltuk megelőzni az osztályfőnökkel, hogy tanulócsoportokat hoztunk létre. Úgy gondoltuk, hogy a diákok között lévő együttmüködés talán jobban, biztonságosabban megtarthatja őket ebben a helyzetben, erősebb hatással tud lenni rájuk, mint a mi próbálkozásaink, és ez bevált. Ezt meg fogjuk tartani a jövőben is, akár online, akár offline oktatás lesz. 2) A sokat hiányzó diákok mindig problémát okoznak az iskolában, de most számukra létrejött egy digitális gyüjtemény a feladatokból, könnyebben hozzáférhetnek a tananyagokhoz, kevésbé tudnak lemaradni, pl. hosszabb betegség után, így ezt is érdemes lenne megtartani. 3) Sok diák felismerte, hogy mi mindenre képes, kompetenciáik fejlődtek, például szerintem önállóbbak lettek. 4) Pozitív tapasztalatom volt, amikor családsegítővel, civil szervezettel kellett együttmüködnöm, úgy éreztem, hogy bizonyos gátak, a formalitás gátjai át tudtak ebben a helyzetben szakadni. 5) A diákokkal egyfajta kötetlenebb, bizalmibb kapcsolat jött létre az online térben. Ami negatívum az oktatás szempontjából, hogy a pedagógusok közül sokan a saját tantárgyukat tartották a legfontosabbnak, nehéz volt arra ösztönözni öket, hogy a helyzetre való tekintettel adjanak alább, alakítsák át kicsit az elvárásaikat.

Bán Dóra: Sikerült egy jó járványügyi protokollt elkészítenünk. A napirendet próbáltuk megtartani, hogy ne jöjjenek ki a ritmusból a szülők és a gyermekek. A járványhelyzet végére felértékelődött az oktatási, nevelési intézmények léte a családok életében. Olyan szinten indultak meg az óvodák, bölcsődék, iskolák felé - mert iszonyatosan elfáradtak a saját gyermekeikkel való intenzív együttlétben -, amilyet korábban sohase tapasztaltam. A terepen dolgozóknak sikerült gyorsan reagálni és mindig egy lépéssel elörébb voltak az útmutatóknál. Sikerült a segítő beszélgetéseket kicsit más irányba elvinni. A bezártságot, a félelmet, a bizonytalanságot próbáltuk együtt legyőzni.

Joó Beatris: Pozitív volt az önkéntes csapatunk kitartása. Pozitívum továbbá, hogy civil szervezetként tudtunk nagyon gyorsan reagálni a tárgyi hiányosságokra és az önkéntes csapat felkészítésére is. A nagyobb gyermekotthonokban kevés nevelő jutott egy gyerekre, ennek következtében szétcsúszott teljesen a napirendjük, senki nem felügyelte őket. Azt tapasztaltuk, hogy a járvány végén ezekkel a gyerekekkel újra fel kell építeni a bizalmi kapcsolatot, maga a rendszeresség azonban fontos volt nekik, mert biztonságot adott. Pozitív még, hogy tudtunk erőforrásokat (szakmai és anyagi) átcsoportosítani a mentálhigiénés fejlesztésre, illetve a szupervíziók sikeressége, ami nagyon jól működött. Szorosabb lett a nevelőkkel is a kapcsolat. A nevelökre, gyermekfelügyelökre nagyon sok teher hárult, hiszen az alapfeladatokon túl a digitális távoktatást is segíteniük kellett. A magánéleti kérdéseket is bevitték sokszor a szupervízióba, nemcsak a szakmai kérdéseket. Sajnos pozitívumként kell megemlíteni azt a tényt, hogy a gyerekeknek az jó volt, hogy az iskolai szegregációnak, bántalmazásnak nem voltak kitéve a home schooling idején. Az Alapítványunk dolgozói, önkéntesei felé irányuló bizalom összességében nőtt az intézmények oldaláról, ezáltal könnyebb lett az együttmüködés. Fontos volt, hogy csapatmunkában tudjunk dolgozni a gyermekek fejlesztésében az önkénteseinkkel, ezáltal alapfeladatunkat, küldetésünket is megvalósítottuk.

Jonkl Marianna: Pozitívum, hogy nekünk nagyon jól sikerült a hálózat tagjaival átállni erre az online térben való munkára. Sokkal erősebb szakmai közösségként jöttünk ki ebből a helyzetből. Megtanultuk, hogy hetente is tudunk találkozni az online térben és sokkal gyorsabban tudunk reagálni szakmai kérdésekre. Nevelőszülöi képzésben elengedhetetlen az internet felhasználói szintű ismerete. A nevelőszülői alkalmassági vizsgálatnál kérdés lehet, 
hogy rendelkeznek-e ilyen eszközökkel, illetve, hogy hogyan támogathatók a nevelöszülök, hogy ezeket az eszközöket be tudják szerezni és tudják is használni a gyermekek nevelése, tanítása során is.

Molnár Zsuzsanna: A saját müködésünkre vonatkoztatva vontuk le a legpozitívabb következtetést, nagyon jól tudtunk együttmüködni, nyílt kommunikációval, kiváló szakmai- és értékközösség alakult ki a csapaton belül. Tanulság viszont, hogy másfajta, közösségi programokat is érdemes odavinnünk a Hös utcába, mint eddig. Tarthatatlan, hogy a társadalom legalján lévők nem kerülnek kapcsolatba a gyermekjóléti alapellátással. Ami nagyon hasznos és fontos, hogy meg kell tartani a civil szervezetekkel a kapcsolatot. A bármilyen módon segíteni szándékozók részére pedig útmutatót szeretnénk készíteni, hogy mi számít segítségnek, hogyan tudnak jól segíteni.

Boros Ilona: Nagyon akartam pozitívumokat keresni, de nem sikerült. Az fantasztikus, hogy hozzátok hasonló civil szervezetek dolgoznak a végeken, és ahogy azt többen említették, a civilek között még szorosabb lett az együttmüködés. De az megengedhetetlen, hogy önkéntes munkában, a civilekre maradjon az állami feladatok ellátása. Elég negatív a prognózisom a jövőre tekintettel, hiszen a gazdasági válság hatásai még nem is érezhetőek, nagyon durva egzisztenciális válság elé néznek az ügyfeleink, és a leszakadó, hátrányos helyzetủ gyermekek helyzetét nézve azt látjuk az utóbbi napok törvénymódosító javaslataiból, hogy a szegregált gyermekekbe és családjaikba szimbolikusan belerúg egyet a kormány, elvitatva tőlük a minőségi oktatáshoz való jogukat - ld. Lex Gyöngyöspata - plusz rendőrt is küld rájuk, gumibottal kezeli a depriváció hatásait - ld. iskolaőrség törvényjavaslat. Ez ijesztő tendencia.

Rácz Andrea: Nagyon fontos, amit behoztál kritikai észrevételként, mert ez a gyermekvédelmi realitásunk. A felmerült témák önmagukban is fontosak, így folytassuk a következö tanévben. Köszönjük a beszélgetést nektek! 